\title{
Effect of Caesalpinia pulcherrima (L。) Sw. seeds on serum glucose and other metabolic parameters of normal and alloxan - induced diabetic rats
}

\author{
M. Balasundaram, ${ }^{1}$ A. Dhanesh Gandhi, ${ }^{1}$ P. Kavitha, ${ }^{2}$ R. Babujanarthanam ${ }^{1 *}$
}

\section{ABSTRACTS}

Oral administration of the ethanol extract of Caesalpinia pulcherrima seeds (CP - 250 and $500 \mathrm{mg} / \mathrm{kg}$ ) caused significant fall in blood glucose levels even at $2 \frac{1}{2} \mathrm{~h}$ after a single dose of treatment in normal fasted and glucose loaded Wistar albino rats. At $250 \mathrm{mg} / \mathrm{kg}$ dose level, CP completely prevented the elevation of blood glucose caused by oral glucose feeding. In alloxan diabetic rats, $\mathrm{CP}$ was able to lower the blood glucose level to around $132 \mathrm{mg} / 100 \mathrm{ml}$ from $10^{\text {th }}$ day and thereafter. The biochemical findings were supported by histopathological studies of liver, kidney and pancreas of control and treated rats. CP was able to increase catalase levels of diabetic rats. Reduced levels of serum protein and elevated levels of Aspartate aminotransferase (AST), Alanine transaminase (ALT), alkaline phosphatase(ALP), cholesterol, triglycerides, creatinine and uric acid were almost normalised in CP treated diabetic rats. $C P$ was also able to reduce in vitro lipid peroxidation in rat liver microsomes and inhibit 1- diphenyl - 2-picryl hydrazyl (DPPH) induced free radicals significantly.

Keywords: Caesalpinia pulcherrima, anti-diabetic, anti-oxidant, alloxan, lipid peroxidation, DPPH quenching,

*Correspondence to: Dr. R. Babujanarthanam, Associate Professor, Department of Biotechnology, Thiruvalluvar University, Serkkadu, Vellore-632115, India. babukmg@gmail.com

Cite This Article:

Balasundaram, M., Dhanesh Gandhi, A., Kavitha, P., Babujanarthanam, R. 2018. Effect of Caesalpinia pulcherrima (L.) Sw. seeds on serum glucose and other metabolic parameters of normal and alloxan - induced diabetic rats . Diabesity 4(2): 9-16. DOl: 10.15562/ diabesity.2018.49

\section{INTRODUCTION}

Medicinal plants are Nature's gift to mankind and they form part of the rich heritage of India. Plant drugs are considered to beless toxic and freefrom side effects than synthetic ones. ${ }^{1}$ Many Indian medicinal plants have been found to be useful in successfully managing diabetes and from some of them, active principles have been isolated. ${ }^{2}$ It is well known that herbal plants like Garlic (Allium sativum), Tulsi (Ocimum sanctum), Neem (Azadirachta indica) and Bitter gourd (Momordica charantia) not only possess hypoglycaemic activity but some of them are hypotensive, hepatoprotective and also blood purifiers. ${ }^{1}$ Caesalpinia pulcherrima (L.) Sw. belonging to the family Caesalpinaceae is known as 'Peacock Flower' or 'Red Bird of Paradise' in English and 'Rajamalli' in Malayalam. It is an exotic, hardy shrub or small tree, growing up to $5 \mathrm{~m}$ in height and cultivated in gardens throughout India. The seeds of $C$ pulcherrima is used in traditional medicine of Kerala to treat diabetes. The roots are used as a remedy for lung and skin diseases. They are prescribed as a decoction for intermittent fevers and in the powdered form for infantile convulsions. The dried and powdered leaves are used to treat in erysipelas. The bark is higly astringent and widely used as an emmenogogue. The flowers are a remedy for intestinal worms. The anti - diabetic effects of Cpulcherima have not scientifically validated yet. In the present study, the effect of Caesalpinia pulcherrima seeds on metabolic parameters of normal and alloxan - induced diabetic rats is reported.

\section{MATERIALS AND METHODS}

\section{Plant material and preparation of the extract}

The seeds of Caesalpinia pulcherrima were collected from Palode, Thiruvananthapuram District, Kerala. They were authenticated by the plant taxonomist of the Institute and a voucher specimen (TBGT 57024 dated 17/ 04 / 07) was deposited at the Institute's Herbarium. The seeds were shade dried and powdered. The powder (100 gm) was successively extracted with $1000 \mathrm{ml}$ of ethanol overnight, at room temperature with constant stirring. The extract was filtered and the filtrate concentrated under reduced pressure to yield $750 \mathrm{mg}$ of the crude extract $(0.75 \%$ with respect to the dried plant material). This crude extract was referred to as CP. It was reconstituted in $0.25 \%$ Tween- 80 , to desired concentrations and used for the experiments.

\section{Animals}

Wistar albino rats, males $(250-300 \mathrm{~g})$ and Swiss albino mice, males $(25-30 \mathrm{~g})$, were obtained from the Institute's Animal House. They were housed under standard laboratory conditions (temperature 
$24-28^{\circ} \mathrm{C}$, relative humidity $60-70 \%$ and $12 \mathrm{~h}$ dark and light cycles) and fed commercial rat feed (Lipton India Ltd., Mumbai, India) and boiled water, ad libitum. All experiments involving animals were carried out according to NIH guidelines, after getting the approval of the Institute's Animal Ethics Committee.

\section{Effect of crude extract (CP) on glucose tolerance}

Rats were divided into 4 groups, of six animals and fasted overnight. Group I, the vehicle control received $1 \mathrm{ml}$ of $0.25 \%$ Tween - 80.Groups II and III were given po, the crude extract, CP (250 and $500 \mathrm{mg} / \mathrm{kg}$ ). Glibenclamide (600 $\mathrm{mg} / \mathrm{kg}$ ) in $10 \%$ Tween - 80 was given to the positive control to group IV. Rats of all the groups were loaded with $60 \%$ glucose (3 g / kg, po), 30 min. after CP administration. Blood samples were collected from the orbital plexus ${ }^{4}$ just prior to drug administration and at $30 \mathrm{~min}, 90$ and $150 \mathrm{~min}$ after glucose loading and glucose levels were determined spectroscopically.

\section{Hypoglycaemic study in normal fasted rats with CP}

Overnight fasted rats were divided into 4 groups of 6 rats each. Group I received $1 \mathrm{ml}$ of $0.25 \%$ Tween 80 (control) and groups II and III received orally CP at $250 \mathrm{mg} / \mathrm{kg}$ and $500 \mathrm{mg} / \mathrm{kg}$ doses. Blood samples were collected from the orbital plexus at 60 and 120 min. after CP administration and glucose levels were measured spectroscopically. Glibenclamide $(600 \mathrm{mg} / \mathrm{kg})$ was administered to Group IV animals (positive control).

Effect of CP on alloxan induced diabetic rats Rats were made diabetic by injecting alloxan $(60 \mathrm{mg} / \mathrm{kg})^{5}$ through tail vein. 5 days later, blood samples were drawn and glucose levels were determined and the diabetic rats exhibiting glucose levels in the range of $400-450 \mathrm{mg} / 100 \mathrm{ml}$ were selected for further studies.

Of the 5 experimental groups, Group I comprised of 6 normal non diabetic control animals and were given a single daily dose of $0.25 \%$ Tween - 80 (1 $\mathrm{ml}$, po), Alloxan induced diabetic rats were divided into 4 groups of 6 rats each (Groups II - V). Group II (alloxan diabetic control) received a single daily dose of $0.25 \%$ Tween - 80 ( $1 \mathrm{ml}$, po), Groups III and IV were administered a single daily dose of CP (250 and $500 \mathrm{mg} / \mathrm{kg}$, po respectively) and GroupV animals received po, $600 \mathrm{mg} / \mathrm{kg}$ of the standard drug, glibenclamide. The treatments were continued for 15 days. Blood samples were collected in the morning, $1 \mathrm{~h}$ after $\mathrm{CP}$ administration on day $1,4,7,10$ and 15 .

\section{Biochemical and histological studies}

On day $15^{\text {th }}$, animals were sacrificed by mild ether anesthesia and blood was collected from all the five groups, for biochemical studies and liver, pancreas and kidney samples were collected for histological studies.

Biochemical parameters like Alanine transaminase (ALT), Aspartate aminotransferase (AST), serum alkaline phosphatase (ALP), cholesterol, total protein, creatinine, uric acid and triglycerides were assayed according to standard methods. ${ }^{6-12}$ Seven $\mu \mathrm{m}$ thick paraffin sections of buffered formalin - fixed liver, pancreas and kidney samples were stained with haematoxylin - eosin for photomicroscopic observations of the organ histological architecture, of the control and treated rats.

\section{Antilipid peroxidation studies}

The antilipid peroxidant effect of CP was studied in vitro, following modified methods. ${ }^{13,14}$ Briefly, $0.5 \mathrm{gm}$ of the rat liver tissue was homogenized with $10 \mathrm{ml}$ of $150 \mathrm{mM}$ KCl-Tris-HCl buffer ( $\mathrm{pH}$ 7.2). $0.25 \mathrm{ml}$ of liver homogenate, Tris - $\mathrm{HCl}$ buffer (pH 7.2), $0.05 \mathrm{ml}$ of $0.1 \mathrm{mM}$ ascorbic acid (AA), $0.05 \mathrm{ml}$ of $4 \mathrm{mM} \mathrm{FeCl}_{2}$ and $0.05 \mathrm{ml}$ of varying concentrations of CP extract. The mixture (in triplicate) was incubated at $37^{\circ} \mathrm{C}$ for $1 \mathrm{hr}$ in capped tubes. Then $0.5 \mathrm{ml}$ of $0.1 \mathrm{~N} \mathrm{HCl}, 0.02 \mathrm{ml}$ of $9.8 \%$ sodium dodecyl sulphate (SDS), $0.9 \mathrm{ml}$ of distilled water and $2 \mathrm{ml}$ of $0.6 \%$ thiobarbituric acid (TBA) was added to each tube and vigorously shaken. All the tubes were then placed in a boiling water bath at $100^{\circ} \mathrm{C}$ for $30 \mathrm{~min}$. After cooling the flocculent precipitate was removed by adding $5 \mathrm{ml}$ of $\mathrm{n}$ - butanol and they were centrifuged at $3000 \mathrm{rpm}$ for $20 \mathrm{~min}$. The absorbance of the supernatant was measured at $532 \mathrm{~nm}$.

\section{DPPH radical scavenging activity}

DPPH radical scavenging activity was measured by the spectrophotometric method. ${ }^{15}$ To an ethanol solution of DPPH $(200 \mu M), 0.05 \mathrm{ml}$ of CP dissolved in ethanol were added at different concentrations $(100-500 \mu \mathrm{g} / \mathrm{ml})$. An equal amount of ethanol was added to the control. After $20 \mathrm{~min}$, the decrease in the absorbance of the test mixture (CP) (due to quenching of DPPH free radicals) was read at $517 \mathrm{~nm}$ and the percentage inhibition calculated by using the formula ${ }^{16}$ given below.

\section{Behavioural and toxic effects}

four groups of 12 mice were administered p.o. 250, 500,1000 and $1500 \mathrm{mg} / \mathrm{kg}$ of the CP extract. They were observed continuously for $1 \mathrm{~h}$ for any gross behavioral changes, symptoms of toxicity and mortality if any and intermittently for the next $6 \mathrm{~h}$ and then again, $24 \mathrm{~h}$ after dosing with CP extract. 


\section{Statistical analysis}

Data were expressed as mean \pm standard deviation of the mean (SD), and statistical comparisons were performed using Student's't' test. ${ }^{17}$

\section{RESULTS}

\section{Effect of CP on blood glucose levels of normal fasted and glucose loaded rats}

Oral administration of CP at $250 \mathrm{mg} / \mathrm{kg}$ showed significant fall in blood glucose level, 2 1/2 hours after a single dose of treatment in normal fasted and glucose loaded rats. CP was effective at $250 \mathrm{mg} / \mathrm{kg}$ dose in depressing the value of blood glucose at $30 \mathrm{~min}$. after glucose loading (Table 1).

\section{Effect of CP on blood glucose levels of hypoglycaemic rats}

CP showed significant hypoglycaemic activity at $250 \mathrm{mg} / \mathrm{kg}$ dose and decreased the blood glucose level significantly up to $120 \mathrm{~min}$ after administration (Table 2).

\section{Effect of CP on blood glucose levels of alloxan - diabetic rats}

The blood glucose levels of alloxan - diabetic rats was in the range of $298-412 \mathrm{mg} / 100 \mathrm{ml}$. In the CP treated group, blood glucose level steadily decreased and it was around $132 \mathrm{mg} / 100 \mathrm{ml}$ on the $10^{\text {th }}$ day. On the $15^{\text {th }}$ day, blood glucose level decreased to around $120 \mathrm{mg} / 100 \mathrm{ml}$. (Table 3).

\section{Effect of CP on other serum biochemical parameters of alloxan diabetic rats}

A significant increase in the Alanine transaminase (ALT), Aspartate aminotransferase (AST) and alkaline phosphatase (ALP) activities were recorded in diabetic rats compared to normal rats, indicating an altered liver function in the diabetic condition. But a significant reduction in the values of ALT, AST and ALP were collectively indicates that the restorations of its activities were found in both CP treated groups compared to diabetic rats. ALT level in group which is treated with CP $500 \mathrm{mg} / \mathrm{kg}$ was found to be $57.31 \pm 6.09$ which is closer to normal control $83.31 \pm 6.12$ than the animals treated with CP $250 \mathrm{mg} / \mathrm{kg}$ their level was $52.32 \pm 6.12$. AST levels were found to be more or less same in all CP and Glibenclamide treated groups and but significantly reduced when compared with diabetic control group. The results of Group 3, treated with CP $250 \mathrm{mg} / \mathrm{kg}$ showed that the ALP level was near normal as in the cases of normal control and Glibenclamide treated group as well. Serum levels of total cholesterol, triglyceride, creatinine and uric acid levels were found to be significantly increased with lowered total protein concentration in the diabetic group. Upon treated with two different dosage levels of CP $250 \mathrm{mg} / \mathrm{kg}$ and $500 \mathrm{mg} / \mathrm{kg}$, the results showed that significant normalization of these elevated serum parameter levels with increased total protein concentration when compared with diabetic control. The results have clearly indicates that the restoration to near normal levels of total cholesterol (50.71 \pm 6.09$)$, creatinine $(0.59 \pm 0.10)$ and uric acid levels $(0.67 \pm 0.12)$ were found in CP with dosage level of $250 \mathrm{mg} / \mathrm{kg}$ treated group. Meanwhile, all other serum biochemical parameters were also found to be more or less at near normal invariably in all the drug treated alloxan induced diabetic rats. (Tables 4 and 5).

\section{Effect of CP on hepatic catalase, glycogen and protein levels}

Administration of CP at 250 and $500 \mathrm{mg} / \mathrm{kg}$ dose raised the activity of CAT in liver tissue of diabetic animals. There was a significant increase in the values of liver glycogen and liver protein in the $\mathrm{CP}$ and standard antidiabetic drug glibenclamide treated groups (Table 6).

\section{Histopathology}

Histopathological observations basically supported the serum parameter assays. Pancreatic sections of diabetic rats showed atrophy of $\beta$ - cells and vascular degenerative changes in islets. $\mathrm{CP}$ and standard antidiabetic drug glibenclamide treated groups treated pancreas showed increase in the islets. Liver tissue of the diabetic rats showed distortion in the arrangement of cells around the central vein and fibrosis. CP treatment restored the cellular arrangement and reduced fibrosis. Kidney sections of diabetic animals showed wall thickening of nephrons and glomerulopathy. $\mathrm{CP}$ treatmet reversed these changes significantly (Figures $1-3, a-d)$.

\section{Effect of CP on in vitro lipid peroxidation}

$\mathrm{CP}$ showed very potent inhibition of $\mathrm{FeCl}_{2}$ - AA stimulated rat liver lipid peroxidation in vitro at concentrations of $1-10 \mu \mathrm{g} / \mathrm{ml}$. There was a significant increase of malondialdehyde (MDA) in $\mathrm{FeCl}_{2}-\mathrm{AA}$ treated rat liver homogenate, compared to normal control without $\mathrm{FeCl}_{2}$ - AA (Table 7).

\section{Effect of CP on DPPH free radical scavenging activity}

CP showed maximum inhibition (75.37 \%) of DPPH free radical at $400 \mu \mathrm{g} / \mathrm{ml} .25 \mu \mathrm{g} / \mathrm{ml}$ dose failed to evoke significant response and it was observed that the free radical was scavenged in a concentration dependent manner upto $400 \mu \mathrm{g} / \mathrm{ml}$. (Table 8). 
Table 1 Effect of ethanol extract of Caesalpinia pulcherrima seeds (CP) on blood glucose levels of normal fasted and glucose loaded rats. [Values are mean \pm SD of 6 animals]

\begin{tabular}{|c|c|c|c|c|}
\hline \multirow[b]{2}{*}{ Groups } & \multicolumn{4}{|c|}{ Blood glucose (mg/100 ml) } \\
\hline & $0 \mathrm{~min}$ & $30 \mathrm{~min}$ & $90 \mathrm{~min}$ & $150 \mathrm{~min}$ \\
\hline Normal control $(0.25 \%$ Tween -80$)$ & $56.0 \pm 5.0$ & $141.0 \pm 3.2$ & $133.0 \pm 4.2$ & $115.0 \pm 1.2$ \\
\hline $\mathrm{CP}(250 \mathrm{mg} / \mathrm{kg})$ & $58.9 \pm 1.4$ & $82.3 \pm 1.7^{* *}$ & $86.3 \pm 1.6^{* *}$ & $81.4 \pm 2.1^{* *}$ \\
\hline $\mathrm{CP}(500 \mathrm{mg} / \mathrm{kg})$ & $53.6 \pm 1.2$ & $108.3 \pm 1.2^{* *}$ & $109.3 \pm 1.6^{* *}$ & $106.3 \pm 1.2^{* *}$ \\
\hline Glibenclamide (600 mg/kg) & $60.1 \pm 1.75$ & $58.1 \pm 1.3^{* *}$ & $40.0 \pm 1.2^{* *}$ & $40.0 \pm 1.3^{* *}$ \\
\hline
\end{tabular}

** Significance $P \leq 0.01$, compared to normal control group

Table 2 Effect of ethanol extract of Caesalpinia pulcherrima (CP) on blood glucose levels of hypoglycaemic rats. [Values are mean \pm SD of 6 animals]

\begin{tabular}{|c|c|c|c|}
\hline \multirow[b]{2}{*}{ Groups } & \multicolumn{3}{|c|}{ Blood glucose (mg/100 ml) } \\
\hline & $0 \mathrm{~min}$ & $60 \mathrm{~min}$ & $120 \mathrm{~min}$ \\
\hline Normal control $(0.25 \%$ Tween -80$)$ & $67.4 \pm 1.8$ & $63.2 \pm 1.7$ & $63.4 \pm 1.3$ \\
\hline $\mathrm{CP}(250 \mathrm{mg} / \mathrm{kg})$ & $66.3 \pm 1.6$ & $46.0 \pm 0.8^{* *}$ & $51.8 \pm 0.9^{* *}$ \\
\hline $\mathrm{CP}(500 \mathrm{mg} / \mathrm{kg})$ & $63.2 \pm 1.6$ & $49.3 \pm 0.7$ & $54.3 \pm 1.0^{* *}$ \\
\hline Glibenclamide $(600 \mathrm{mg} / \mathrm{kg})$ & $65.1 \pm 1.3$ & $58.1 \pm 1.3^{* *}$ & $60.0 \pm 1.3^{* *}$ \\
\hline
\end{tabular}

** Significance $P \leq 0.01$, compared to normal control group

Table 3 Effect of ethanol extract of Caesalpinia pulcherrima (CP) on blood glucose levels of alloxan - diabetic rats. [Values are mean \pm SD of 6 animals]

Blood glucose levels (mg / 100ml)

\begin{tabular}{|c|c|c|c|c|c|}
\hline Groups & Day 1 & Day 4 & Day 7 & Day 10 & Day 15 \\
\hline $\begin{array}{l}\text { Normal Control } \\
(0.25 \% \text { Tween } 80)\end{array}$ & $88.0 \pm 4.2$ & $89.3 \pm 3.9$ & $85.3 \pm 4.0$ & $88.0 \pm 5.1$ & $86.0 \pm 4.0$ \\
\hline $\begin{array}{l}\text { Alloxan Control } \\
(60 \mathrm{mg} / \mathrm{kg})\end{array}$ & $298.0 \pm 6.3$ & $372.1 \pm 2.6$ & $412.3 \pm 1.5$ & $365.2 \pm 1.8$ & $363.2 \pm 1.9$ \\
\hline CP $(250 \mathrm{mg} / \mathrm{kg})$ & $284 . \pm 6.1$ & $210.2 \pm 5.1^{\star *}$ & $170.2 \pm 3.4^{* *}$ & $132.2 \pm 1.6^{* *}$ & $120.1 \pm 4.3^{* *}$ \\
\hline CP $(500 \mathrm{mg} / \mathrm{kg})$ & $216.3 \pm 4.3$ & $220.2 \pm 3.9^{* *}$ & $182.8 \pm 4.2^{* *}$ & $138.1 \pm 2.3^{* *}$ & $126.3 \pm 2.1^{* *}$ \\
\hline $\begin{array}{l}\text { Glibenclamide } \\
(600 \mathrm{mg} / \mathrm{kg})\end{array}$ & $286.1 \pm 2.3^{* *}$ & $207.1 \pm 2.1^{* *}$ & $166.4 \pm 2.1^{* *}$ & $128.2 \pm 4.3^{* *}$ & $115.3 \pm 4.1^{* *}$ \\
\hline
\end{tabular}

** Significance $P \leq 0.01$, compared to alloxan control group

Table 4 Effect of ethanol extract of Caesalpinia pulcherrima (CP) on other serum biochemical parameters of alloxan diabetic rats. [Values are mean \pm SD of 6 animals]

\begin{tabular}{lccc}
\hline Groups & ALT (IU/L) & AST (IU/ L) & ALP (IU/L) \\
\hline Normal Control (0.25\% Tween 80) & $83.31 \pm 6.12$ & $123.21 \pm 6.23$ & $207.31 \pm 9.01$ \\
Alloxan Control (60 mg/ kg) & $142.23 \pm 7.11$ & $251.32 \pm 6.09$ & $299.32 \pm 6.12$ \\
Alloxan + CP (250 mg/kg) & $52.32 \pm 6.12^{* *}$ & $200.31 \pm 8.02^{* *}$ & $214.36 \pm 7.23^{* *}$ \\
Alloxan + CP (500 mg/kg) & $57.31 \pm 6.09^{* *}$ & $210.26 \pm 3.12^{* *}$ & $220.71 \pm 6.21^{* *}$ \\
Alloxan + Glibenclamide (600mg/kg) & $61.32 \pm 7.11^{* *}$ & $203.26 \pm 9.12^{* *}$ & $209.73 \pm 8.17^{* *}$ \\
\hline
\end{tabular}

** Significance $P \leq 0.01$, compared to alloxan control group 
Table 5 Effect of ethanol extract of Caesalpinia pulcherrima seed extract (CP) on rat serum cholesterol, total protein, triglycerides, creatinine and uric acid after alloxan administration. [Values are mean \pm SD of 6 animals]

\begin{tabular}{|c|c|c|c|c|c|}
\hline Groups & $\begin{array}{l}\text { Cholesterol } \\
\text { (mg / dl) }\end{array}$ & $\begin{array}{l}\text { Total Protein } \\
\text { (mg / dl) }\end{array}$ & $\begin{array}{l}\text { Triglycerides } \\
(\mathrm{mg} / 100 \mathrm{ml})\end{array}$ & $\begin{array}{l}\text { Creatinine } \\
(\mathrm{mg} / 100 \mathrm{ml})\end{array}$ & $\begin{array}{c}\text { Uric acid } \\
(\mathrm{mg} / 100 \mathrm{ml})\end{array}$ \\
\hline Normal Control (0.25\% Tween 80$)$ & $50.31 \pm 9.27$ & $407.31 \pm 8.29$ & $86.83 \pm 5.5$ & $0.52 \pm 0.1$ & $0.68 \pm 0.016$ \\
\hline Alloxan control $(60 \mathrm{mg} / \mathrm{kg})$ & $87.33 \pm 8.19$ & $373.36 \pm 8.12$ & $200.83 \pm 11.1$ & $1.35 \pm 0.1$ & $0.556 \pm 0.055$ \\
\hline Alloxan + CP (250 mg/kg) & $50.71 \pm 6.09^{* *}$ & $398.31 \pm 6.21^{* *}$ & $110.31 \pm 6.26^{* *}$ & $0.59 \pm 0.10^{* *}$ & $0.67 \pm 0.12^{* *}$ \\
\hline Alloxan + CP (500 mg/kg) & $53.32 \pm 7.13^{* *}$ & $395.32 \pm 6.11^{* *}$ & $117.61 \pm 3.15^{* *}$ & $0.65 \pm 0.12^{* *}$ & $0.63 \pm 0.017^{* *}$ \\
\hline $\begin{array}{l}\text { Alloxan + Glibenclamide } \\
(600 \mathrm{mg} / \mathrm{kg})\end{array}$ & $45.71 \pm 8.11^{* *}$ & $390.33 \pm 9.09^{* *}$ & $108.00 \pm 6.1^{* *}$ & $0.58 \pm 0.1^{* *}$ & $0.63 \pm 0.006^{* *}$ \\
\hline
\end{tabular}

** Significance $P \leq 0.01$, compared to alloxan control.

Table 6 Effect of ethanol extract of Caesalpinia pulcherrima seed extract (CP) on hepatic catalase, glycogen and protein levels. [Values are mean \pm SD of 6 animals]

\begin{tabular}{lccc}
\hline Groups & $\begin{array}{c}\text { Catalase } \\
(\mathbf{~ m g} / \mathbf{g})\end{array}$ & $\begin{array}{c}\text { Glycogen } \\
(\mathbf{m g} / \mathbf{g})\end{array}$ & $\begin{array}{c}\text { Protein } \\
(\mathbf{m g} / \mathbf{g})\end{array}$ \\
\hline Normal Control $(0.25 \%$ Tween- 80$)$ & $3.00 \pm 0.10$ & $50.00 \pm 2.00$ & $16.00 \pm 1.20$ \\
Alloxan control (60 mg/ kg) & $0.88 \pm 0.01$ & $26.00 \pm 1.50$ & $8.60 \pm 2.60$ \\
Alloxan + CP (250 mg/kg) & $2.75 \pm 0.02^{* *}$ & $38.00 \pm 3.60^{* *}$ & $14.20 \pm 1.30^{* *}$ \\
Alloxan + CP (500 mg/kg) & $2.52 \pm 0.004^{* *}$ & $32.00 \pm 3.60^{* *}$ & $12.50 \pm 1.20^{* *}$ \\
Alloxan + Glibenclamide (600mg/kg) & $2.45 \pm 0.05^{* *}$ & $37.00 \pm 4.00^{* *}$ & $12.00 \pm 1.20^{* *}$ \\
\hline
\end{tabular}

** Significance $P \leq 0.01$, compared to alloxan control

Table 7 Effect of ethanol extract of Caesalpinia pulcherrima seed extract (CP) on $\mathrm{FeCl}_{2}$ - ascorbic acid (AA) - induced lipid peroxidation in rat liver homogenate in vitro. [Values are mean \pm SD of 3 experiments]

\begin{tabular}{lccc}
\hline Groups & $\begin{array}{c}\text { CP Concentration } \\
\text { (mg / ml) }\end{array}$ & $\begin{array}{c}\text { MDA } \\
\text { ( n mole / g wet liver) }\end{array}$ & MDA \\
\hline Normal Control & - & $1.34 \pm 0.60$ & - \\
$\mathrm{FeCl}_{2}-\mathrm{AA}$ control & - & $2.69 \pm 0.02$ & - \\
$\mathrm{FeCl}_{2}-\mathrm{AA}+\mathrm{CP}$ & 1.00 & $1.89 \pm 0.02$ & $49.60^{* *}$ \\
$\mathrm{FeCl}_{2}-\mathrm{AA}+\mathrm{CP}$ & 5.00 & $1.63 \pm 0.01$ & $56.53^{* *}$ \\
$\mathrm{FeCl}_{2}-\mathrm{AA}+\mathrm{CP}$ & 10.00 & $1.96 \pm 0.02$ & $47.73^{* *}$ \\
\hline$* * \mathrm{Sign}^{*}$
\end{tabular}

** Significance $P \leq 0.01$, compared to $\mathrm{FeCl}_{2}$ - AA Control

Table 8 Effect of ethanol extract of Caesalpinia pulcherrima seed extract (CP) on DPPH radical scavenging activity [Values are mean of 3 experiments]

\begin{tabular}{ccc}
\hline Conc $(\boldsymbol{\mu g} / \mathbf{m l})$ & DPPH (\% Inhibition) \\
\hline 25 & 42.75 \\
50 & 63.75 & 62.75 \\
100 & 70.00 \\
200 & 75.37 & 73.77
\end{tabular}



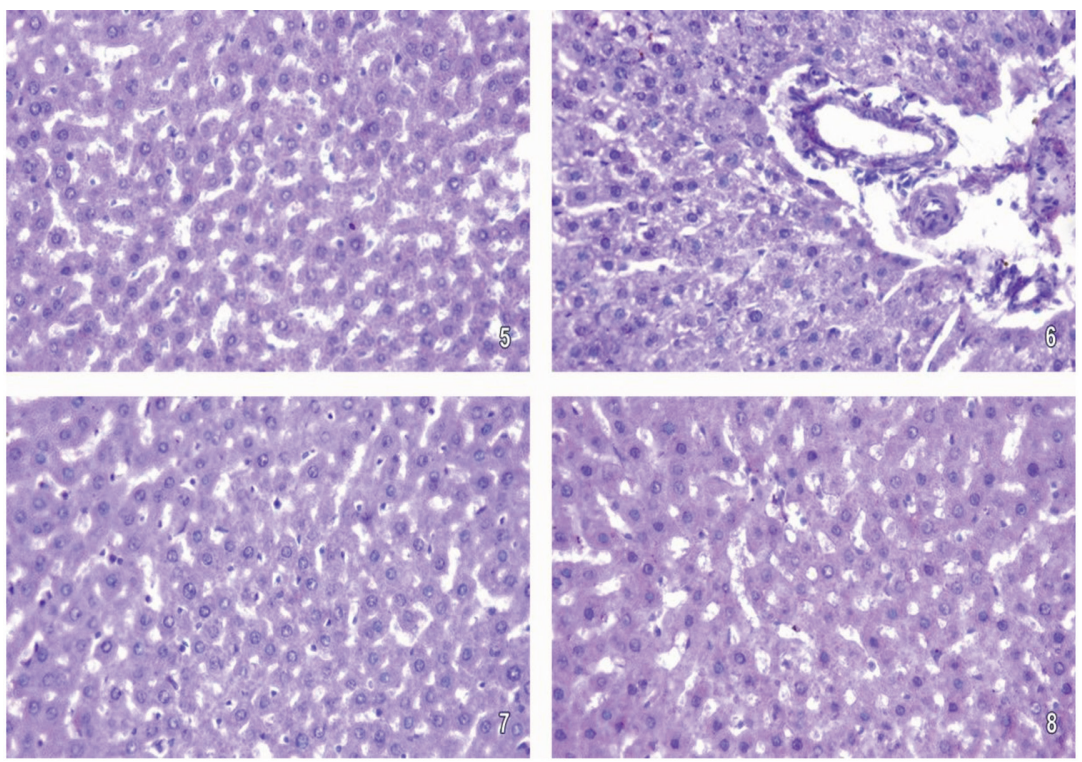

Figure 1 Histological evidence of the protective effect of ethanol extract of seeds of Caesalpinia pulcherrima (CP) /glibenclamide on liver of alloxan induced diabetes in Wistar rats. (a). Normal control showing hepatocytes with well brought out nuclei and cytoplasm (x 300). (b). Liver of diabetic rat showing degenerated parenchymatous cells with severe necrosis and dilation of sinusoids (x 300). (c). Liver of diabetic rat after treatment with $\mathrm{CP}$, showing hepatocytes with nearly normal appearance and minimal necrosis(x 300). (d). Liver of diabetic rat after treatment with glibenclamide showing normal hepatocytes (x 300)

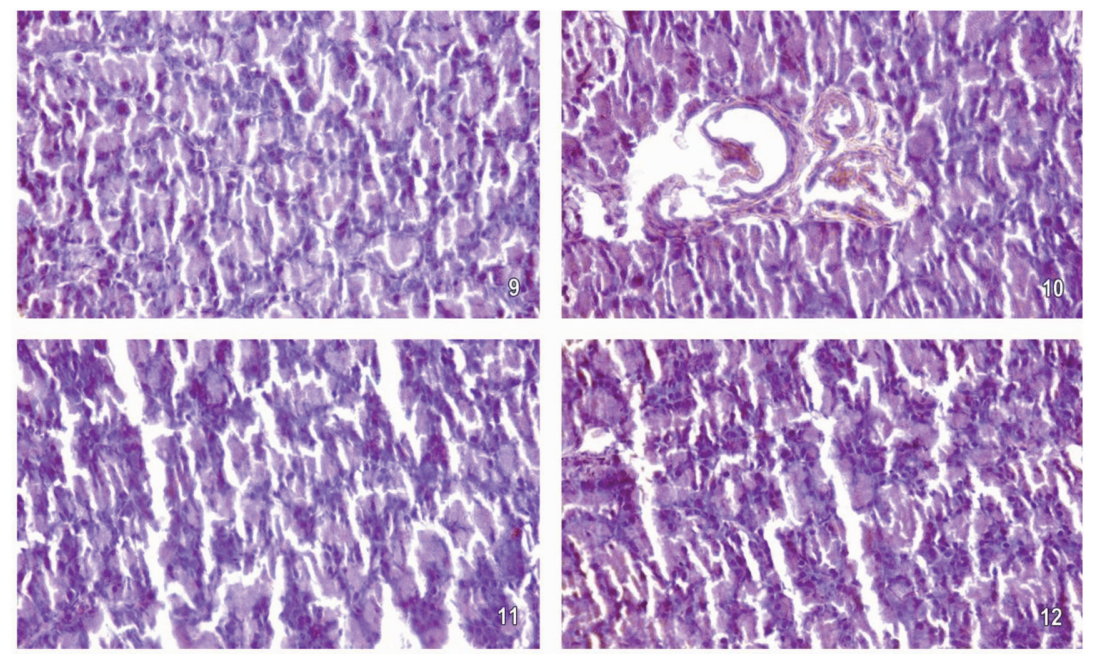

Figure 2 Histological evidence of the protective effect of ethanol extract of seeds of Caesalpinia pulcherrima (CP) / glibenclamide on pancreas of alloxan induced diabetes in Wistar rats. (a). Normal control showing abundant patches of $\beta$ - cells (x 300). (b). Pancreas of diabetic rat showing minimal pancreatic $\beta$ - cells (x 300). (c). Pancreas of diabetic rat after treatment with CP seed extract showing pancreatic $\beta$ - cells almost similar to that of control (x 300). (d). Pancreas of diabetic rat after treatment with glibenclamide, showing pancreatic $\beta$ - cells similar to that of the control (x 300)

\section{Toxicity studies}

In the acute toxicity studies, $\mathrm{CP}$ was found to be nontoxic up to the highest dose used (1500 mg $/ \mathrm{kg}$ ), The $\mathrm{LD}_{50}$ of CP was therefore above $1500 \mathrm{mg} / \mathrm{kg}$ in mice (data not shown).

\section{DISCUSSION}

Diabetes Mellitus (DM) is a major public problem world wide. ${ }^{18}$ Many oral hypoglycemic agents are not very effective in lowering glucose in diabetic patients. ${ }^{19}$ Therefore, the search for effective drugs for the treatment of diabetes mellitus continues. Many herbs have been shown to have hypoglycemic action in animals and humans. ${ }^{20,21}$ There are several reports on the antidiabetic properties of Terminalia catappa, Momordica charantia ${ }^{22}$ elumbo nucifera ${ }^{23}$ etc. The present study reports for the first time the anti - hyperglycemic and anti - diabetic effects of Caesalpinia pulcherrima in rats. CP exhibited anti hyperglycemic effects in normal fasted and alloxan induced diabetic rats. The effect was comparable to glibenclamide, the positive control used in this study. Alloxan induces diabetes by destroying the b cells and the destruction is almost complete and it impairs renal function. In the present study, CP significantly reduced the blood glucose levels of alloxan diabetic rats indicating the mechanism of action may be due to potentiation of insulin release from the surviving pancreatic cells, but due possibly to increased peripheral glucose utilization and inhibition of proximal tubular re absorption of glucose in the kidney. ${ }^{24}$

CP was also found to be an effective agent against other metabolic alterations induced as a consequence of diabetes. Insulin deficiency leads to various metabolic alterations in the animals like increased blood, cholesterol, triglycerides, AST, ALT, ALP and decreased levels of serum proteins. ${ }^{25}$ In the present study, the levels of all the above parameters were almost normalized by CP treatment this is due to an improvement in carbohydrate, fat and protein metabolism. The restoration of AST and ALP after treatment with CP also indicates a revival in insulin secretion. $\mathrm{CP}$ was able to increase the levels of catalase of diabetic rats, thereby helping to detoxify the deleterious free radicals. It may prevent the formation of free radicals or it may scavenge the reactive oxygen metabolites through its antioxidant phytocompounds. In chronically diabetic animals, with high glucose levels, a decrease in liver glycogen could be attributed to the lesser availability of the enzyme glycogen synthase which in turn has been reported to be responsible 

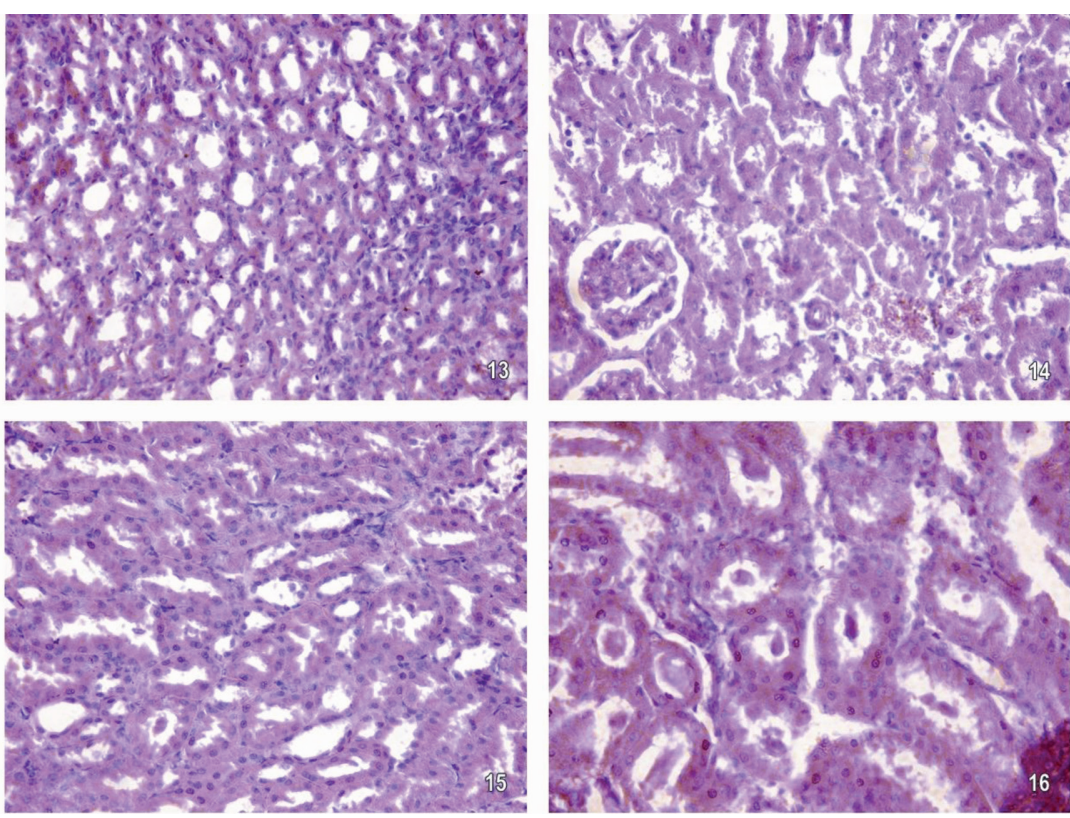

Figure 3 Histological evidence of the protective effect of ethanol extract of seeds of Caesalpinia pulcherrima (CP) / glibenclamide on kidney of alloxan induced diabetes in Wistar rats.(a).Normal control kidney showing normal Bowman's capsule and renal tubules (x 300). (b). Kidney of diabetic rat showing degenerative changes, expanded glomerulus and thickening of the walls of renal tubules (x 300). (c). Kidney of diabetic rat after treatment with CP showing glomerulus with reduction in thickening of walls of renal tubules (x 300). (d). Kidney of diabetic rat after treatment with glibenclamide showing normalcy of Bowman's capsule (x 300)

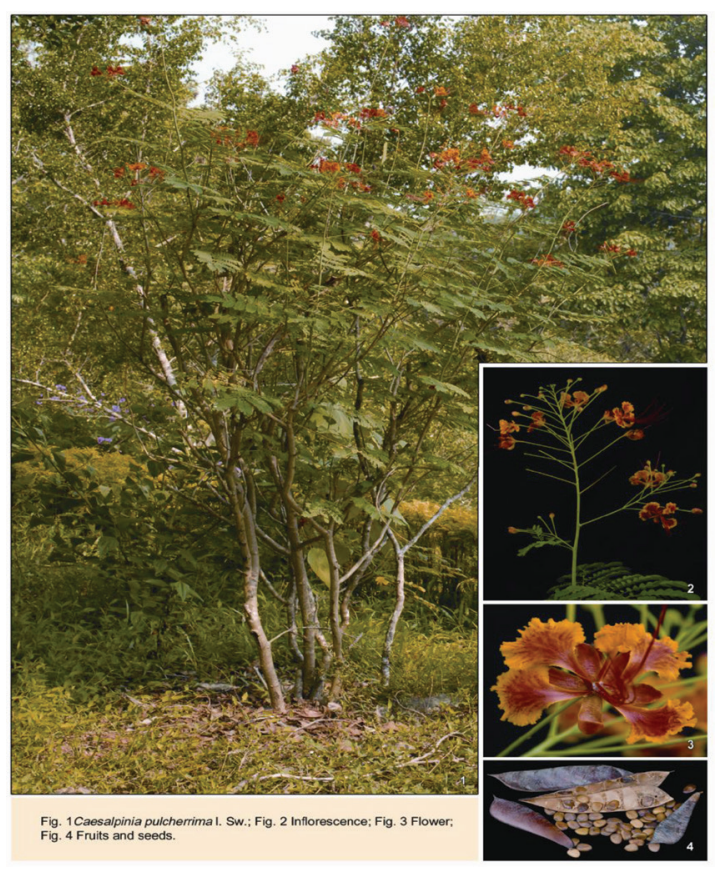

for the incorporation of glucose moieties into the preexisting glycogen chain. In the present study, the normalization of depressed glycogen level by $\mathrm{CP}$ may be due to the regulation of glucose metabolism as reported by Dhawan et $\mathrm{al}^{26}$ with the herbal anti diabetic formulation, D - 400.

Histopathological studies of pancreas, liver and kidney of control and CP treated diabetic rats, supported the results obtained from biochemical analysis CP treatment protected the pancreas which showed increased number of islets compared to alloxan diabetic control. Similarly the histopathological changes in the liver and kidneys were more or less normalized by CP treatment.

\section{CONCLUSION}

From the results, it is clear concluded that CP contained active phytocompounds capable of stimulating the surviving $b$ cells of the pancreas damaged by alloxan, to release more insulin and perhaps the phytocompounds of CP were of an anti oxidant nature. Free radicals produced by alloxan are known to cause pancreatic damage. Phytochemical studies of $C$ pulcherrima reported the presence of tannins and flavonoids ${ }^{27}$ which are known to have antidiabetic properties. ${ }^{28} \mathrm{CP}$ also showed anti lipid peroxidation and free radical scavenging effects. Thus it acts as an antioxidant and protects the liver, kidneys and pancreas from free radical damage. Thus $\mathrm{CP}$ appears to be an attractive material for further studies, leading to possible drug development for diabetes.

\section{ACKNOWLEDGEMENT}

Thanks are due to Dr. S. Ganeshan, Director, TBGRI for facilities, K P Pradeep Kumar for photographic assistance and S Radhakrishna Pillai for technical assistance.

\section{CONFLICT OF INTEREST}

Authors do not have conflict of interest.

\section{REFERENCES}

1. Momin A, Role of Indigenous Medicine in Primary HeASTh Care. Proceedings of First International Seminar on Unani Medicine, (New Delhi) 1987, 54.

2. Shukla R, Sharma S B, Puri D, Prabhu K M \& Murthy P S, Medicinal plants for treatment of diabetes mellitus, Indian J Clin Biochem, 15 (2000) 169.

3. Tiwari A K \& Rao M, Diabetes mellitus and multiple therapeutic approaches of phytochemicals: present status and future prospects, Curr Sci, 83 (2002) 30.

4. Waynforth H B, Experimental and Surgical Techniques in the Rat, (Academic Press,London) 1980, 160.

5. Babu V, Gangadevi T \& Subramoniam A, Antihyperglycaemic activity of Cassia kleinii leaf extract in glucose fed normal rats and alloxan induced diabetic rats, Indian J Pharmacol, 34 (2002) 409.

6. Reitman S \& Frankel S, Determination of serum glutamate oxaloacetate and glutamic pyruvic acid transaminases, Amer J Clin Pathol, 28 (1957) 56. 
7. Kind P R N \& King E J, Estimation of plasma phosphatase by determination of hydrolysed phenol with amino anti pyrine, J Clin Pathol, 7 (1954) 322.

8. Zak B, Boyle A J \& Zlatkis A, A method for the determination of cholesterol, J Clin Med,41(1953)48.

9. Lowry H D, Rosenberg N J, Farr A L \& Randall R S, Protein measurement with Folin's phenol reagent, J Biol Chem, 193 (1951) 265.

10. Bowers L D, Kinetic serum creatinine assays I. The role of various factors in determining specificity, Clin Chem 26, (1980) 551.

11. Eichhom E, Zalma waki S, Rotenburg E A \& Fanis B,Uric acid estimation in serum and urine, J Clin Pathol, 14, (1961) 450. 12

12. Muller P H, Schmulling RM, Liebich H \& Eggstein M, A fully enzymatic triglyceride determination, $J$ Clin Chem 15 (1977) 457.

13. Yoshiyuki K, Michinori K, Tadoto T, Shigree A \& Hiromichi O, Studies on Scutelariae radix, Effect of lipid peroxidation of rat liver, Chem Pharm Bull, 29 (1981) 2610.

14. Masao H, Yang X W, Migashiro H \& Namba T, Inhibitory effects of monomeric and dimeric phenyl propanoids on lipid peroxidation in vivo and in vitro,Phytother Res, 7 (1993) 395.

15. Sreejayan N \& Rao M N A, Free radical scavenging activity by curcuminiods.Drug Res, 46 (1996) 169.

16. Prasanth Kumar V, Shasidhara S,Kumar M M \& Sridhara B Y,Effect of Luffa echinata on lipid peroxidation and free radical scavenging activity, J Pharm. Pharmacol, 52 (2000) 891.

17. Snedecor G W \& Cochran W G, Statistical Methods (Iowa State University Press, Iowa, USA) 1980, 75.

18. Wild S, Roglic G, Green A, Sicre R \& King H, Global prevalence of diabetes estimates for the year 2000 and projections for 2030, Diabetes Care, 27 (2004) 1047.

19. Nagarajan S, Jain H C \&Aulakh G S, Indigenous Plants Used in the Control of Diabetes. (Council of Scientific and Industrial Research, New Delhi) 1987,588.
20. Twaij H A A \& Al-Badr,Hypoglycaemic activity of Artemisia herba alba,J Ethnopharmacol, 24 (1988) 123.

21. Gupta S S, Prospects and perspectives of natural plant products in medicine, Indian J Pharmacol, 26 (1994) 5.

22. Ansari Z \& Nehal M, Hypoglycaemic effect of Momordica charantia seed mediates through extrapancreatic actions, $J$ Sci Pharm, 4 (2003) 65.

23. Mukheriee P K, Saha K, Pal M \& Saha B P, Effect of Nelumbo nucifera rhizome extract on blood glucose levels in rats, J Ethnopharmacol, 58 (1997) 207.

24. Sharma M K, Khara A K \& Feroz H, Effect of neem oil on blood glucose levels of normal, hyperglycaemic and diabetic animals, Indian Med Gaz, 117 (1983) 380.

25. Dhanabal S P, Kokati C K, Ramanathan M, Kumar E P \& Suresh B, Hypoglycaemic activity of Pterocarpus marsupium Roxb, Phytother Res 20 (2006) 4.

26. Dhawan D, Bandhu H K, Singh B, Singh \& Nagpal J P, Effect of Securigera securidaca on blood glucose levels of normal and alloxan induced diabetic rats, Pharmaceut Biol, 39 (1996) 62.

27. Ohiri F C, Esimone C O, Nwafor S V, Okoli C O \& Ndu O O, Hypoglycaemic properties of Viscum album (Mistletoe) in alloxan induced diabetic animals, Pharmaceut Biol, 41 (2003) 184

28. Kameswararao B, Renuka S P, Rajasekhar M D, Nagaraju N \& Apparao C $\mathrm{H}$, Antidiabetic activity of Terminalia pallida fruit in alloxan- induced diabetic rats, $\mathrm{J}$ Ethnopharmacol, 85 (2002) 169.

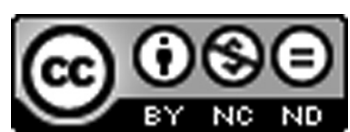

This work is licensed under a Creative Commons Attribution-Non Commercial-No Derivatives 4.0 International License. To view a copy of this license, visit http://creativecommons.org/licenses/by-nc-nd/4.0/ 